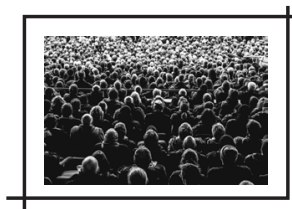

\title{
A CONSTRUÇÃO DE JOÃO GOULART COMO PERSONAGEM HISTÓRICO ŅO FILME JANGO (1984), DIREÇÃO DE SILVIO TENDLER: BREVES REFLEXÕES SOBRE A ESCRITA DA HISTÓRIA A PARTIR DO CINEMA DOCUMENTÁRIO
}

\author{
Rodrigo Francisco Dias*
}

Resumo: Este artigo aborda as relações entre cinema documentário e história do Brasil a partir do filme Jango (1984), direção de Silvio Tendler. Por meio da análise dos aspectos formais/estéticos do documentário, sobretudo no que diz respeito à construção do personagem histórico João Goulart no interior da narrativa fílmica, procuramos demonstrar como se deu o posicionamento político-ideológico do cineasta Silvio Tendler no contexto de produção e lançamento do filme. A análise do documentário mostra que a narrativa fílmica construída pelo cineasta Silvio Tendler tem como uma de suas principais características uma série de estratégias narrativas (depoimentos, edição, trilha sonora, seleção de imagens, narração em voz over) que contribuem para que o político João Goulart seja descrito no filme de maneira bastante positiva. Argumentamos que, no documentário, João Goulart desempenha o papel de um "herói trágico" no âmbito da recente história política brasileira. Nesse sentido, chamamos a atenção para o fato de que os elementos estéticos/formais do documentário não foram definidos ao acaso, mas sim com base no posicionamento político-ideológico assumido pelo cineasta quando o filme foi produzido e lançado, época em que o Brasil passava pelo processo de transição da ditadura para a redemocratização. Para além de estabelecer um diálogo entre o documentário e o contexto histórico em que ele foi produzido e lançado, pretendemos demonstrar como o filme levanta questões muito pertinentes acerca da escrita da história.

Palavras-chave: Cinema documentário. Silvio Tendler. História do Brasil. João Goulart. Herói trágico.

\section{INTRODUÇÃO}

No primeiro volume da trilogia Tempo e narrativa, escrita por Paul Ricoeur (2010a), há um momento em que o filósofo francês tece um instigante comentário a respeito da relação

\footnotetext{
* Doutor em História pela Universidade Federal de Uberlândia (UFU). Professor do Ensino Básico, Técnico e Tecnológico do Instituto Federal de Educação, Ciência e Tecnologia de Minas Gerais (IFMG).E-mail: dias.rodrigof@gmail.com
} 
entre o narrador de uma história e os personagens da história narrada. Segundo Ricoeur (2010a), o ato de narrar as ações realizadas por determinado personagem envolve quase sempre um julgamento de ordem moral a respeito dessas ações, pois o narrador não está jamais em uma posição de neutralidade, de modo que ele costuma classificar certas ações humanas como boas ou más. 0 autor também observa que é possivel identificar o tipo de julgamento moral feito pelo narrador a respeito dos personagens de uma certa história a partir dos próprios elementos estéticos da narrativa. Não por acaso, Ricoeur (2010a) faz referência à Poética de Aristóteles e aos gêneros da tragédia e da comédia: enquanto a tragédia tende a representar os homens "melhores", a comédia tende a representá-los "piores" do que os "homens atuais". A opção estética de narrar uma história sob a forma de uma tragédia ou sob a forma de uma comédia já é um indício de como o narrador julgou - como boas ou más - as ações dos personagens da narrativa (RICOEUR, 2010a).

Vale lembrar que o objetivo principal de Paul Ricoeur quando escreveu os três volumes de Tempo e narrativa era compreender as relações entre tempo e narrativa a partir de um conjunto de reflexões a respeito tanto do campo da historiografia - as narrativas escritas pelos historiadores profissionais - quanto do campo das narrativas ficcionais. No terceiro volume da trilogia, ao articular história, ficção e tempo, Paul Ricoeur (2010b, p. 311) defende a tese de que há um "entrecruzamento entre história e ficção", entrecruzamento definido por ele como "a estrutura fundamental, tanto ontológica como epistemológica, em virtude da qual a história e a ficção só concretizam suas respectivas intencionalidades tomando de empréstimo a intencionalidade da outra".

Ricoeur (2010b) reconhece que, nessa referência cruzada entre história e ficção, cada uma das duas possui as suas especificidades, uma vez que, segundo o autor, o tempo fictício e o tempo histórico diferem na medida em que o narrador de ficção está livre das obrigações que se impõem ao historiador. Ainda de acordo com o autor, tal entrecruzamento entre história e ficção se dá quando o historiador pretende tratar da realidade do passado, um tempo histórico anterior, por meio de uma operação que utiliza estratégias narrativas próximas daquelas da ficção, enquanto o narrador de ficção, por sua vez, narra acontecimentos que, embora tenham sido inventados, de alguma maneira remetem também ao mundo exterior ao texto. Dito de outra forma, Ricoeur (2010b, p. 268) problematiza tanto a noção de realidade do passado quanto a noção de irrealidade da ficção, situando o entrecruzamento entre história e ficção em um ponto no qual, segundo suas palavras, "descobrir e inventar são indiscerníveis".

Fizemos questão de iniciar o presente texto retomando alguns elementos da trilogia Tempo e narrativa, de Paul Ricoeur, porque eles nos parecem particularmente úteis para pensar sobre as múltiplas formas de se narrarem as ações e as trajetórias de certos personagens, sejam eles históricos, sejam fictícios. Atualmente, entre os historiadores, já não é nenhuma novidade reconhecer que não existem fronteiras rígidas separando história e ficção. Todavia, 
embora muitos historiadores afirmem que eles também são narradores, o fato é que, como bem observou Peter Gay (1990, p. 168), "muitas obras históricas não têm sequer um vago conhecimento da arte do escritor", de modo que muitos textos escritos por historiadores não são agradáveis de ser ler, principalmente para o público geral. Diante disso, não é de se estranhar que, atualmente, muitos produtos culturais como livros, filmes e séries televisivas realizados por outros profissionais (como jornalistas e cineastas, por exemplo) e que tratam de temas históricos geralmente alcançam um público maior do que aquele alcançado pelos próprios historiadores, uma vez que tais produções costumam ser mais agradáveis de se ler/ assistir do que os artigos e livros de autoria dos historiadores. Há também a percepção de que, com a existência de tantas narrativas históricas produzidas por não historiadores, a dita historiografia profissional tem ficado cada vez mais desprovida de autoridade, legitimidade e credibilidade junto ao público geral (MALERBA, 2017).

Se falta a muitos historiadores a habilidade de elaborar narrativas que tenham de fato algum mérito do ponto de vista literário/estético, uma questão que surge é: como produzir narrativas históricas que também sejam agradáveis ao leitor? Acreditamos que um procedimento importante para alcançar tal resultado é ter certo cuidado quando da caracterização dos personagens históricos no texto do historiador. Uma narrativa com personagens interessantes e complexos tem mais chances de despertar o interesse de um público maior. Todavia, como muitos historiadores não receberam ao longo de sua formação universitária subsídios adequados para realizar tal empreitada, permanece o dilema: como proceder?

Acreditamos que o diálogo da História enquanto área do conhecimento humano com o cinema documentário pode instigar os historiadores a uma postura menos negligente quanto à forma assumida por suas narrativas históricas. No intuito de demonstrar como isso pode ser feito, vejamos o caso do documentário Jango (1984), uma obra cinematográfica que, em nossa avaliação, mostra muito bem como certas opções estéticas/formais podem ser mobilizadas quando da construção de um personagem histórico em uma narrativa. Para uma análise mais profícua desse filme, iremos na próxima seção abordar alguns aspectos da trajetória do cineasta Silvio Tendler, com destaque para o contexto de produção do filme Jango. Em seguida, faremos uma análise mais detalhada dos aspectos estéticos/formais do documentário, com destaque para aqueles relacionados à construção do personagem histórico João Goulart no interior da narrativa filmica. Esperamos com isso demonstrar o modo como o cineasta se posicionou em relação às ações do protagonista de seu filme, produzindo uma obra cinematográfica não só capaz de refletir criticamente sobre alguns momentos da recente história política do Brasil, mas também de preencher de emoção a interpretação histórica presente no documentário. Ao tomar o filme Jango como objeto de estudo, pretendemos contribuir para as discussões a respeito da escrita da História. Dito isso, passemos à próxima seção. 


\section{O CINEASTA SILVIO TENDLER E A PRODUÇÃO DO FILME JANGO}

0 cineasta brasileiro Silvio Tendler nasceu no Rio de Janeiro em 1950 e fez o curso de Cinema no Museu de Arte Moderna (MAM), também no Rio de Janeiro. Em 1968, foi presidente da Federação de Cineclubes. Entre 1970 e 1972 trabalhou em programas de cultura popular no Chile. Obteve láurea em História na Universidade de Paris e mestrado em Cinema e História (com um trabalho sobre Joris Ivens). Fez ainda o curso de Cinema Aplicado à Ciência Social com o antropólogo Jean Rouch durante o período entre 1972 e 1976 (MIRANDA, 1990). Como se vê, o diálogo com a História foi peça importante já na sua formação como cineasta.

Na sua filmografia, destacam-se obras como Os Anos JK - uma trajetória política (1980), O mundo mágico dos Trapalhões (1981), Jango (1984), Encontro com Milton Santos: o mundo global visto do lado de cá (2006), Utopia e barbárie (2009), Tancredo - a travessia (2011), Militares da democracia: os militares que disseram não (2014) e Os advogados contra a ditadura: por uma questão de justiça (2014)'. Em texto publicado por Amir Labaki na Folha de S.Paulo no dia 21 de junho de 2018, Silvio Tendler foi definido como "um dos mais marcantes e prolíficos documentaristas da história do cinema brasileiro". Ainda segundo Labaki (2018), a formação de Silvio Tendler como cineasta passou pelo contato com o "triunvirato de documentaristas socialistas formado por Chris Marker, Joris Ivens e Santiago Alvarez". Utilizando-se de narrações em off, depoimentos e materiais de arquivo, Tendler produziu ao longo de sua trajetória como cineasta filmes com um forte cunho social, o que fica visivel também em alguns de seus filmes mais recentes, tais como as duas partes de 0 veneno está na mesa (2011 e 2014), Privatizações: a distopia do capital (2014) e Dedo na ferida (2017), obras nas quais o cineasta assumiu como vetor temático a denúncia do capitalismo globalizado (LABAKI, 2018).

Em entrevista concedida ao Blog Junho, Silvio Tendler recordou que era um garoto de 14 anos quando do advento do golpe de 1964 e que, já no início da ditadura, posicionou-se contra o regime, dando uma "guinada à esquerda" rumo ao socialismo em sua vida, seja pelo viés da arte (em especial, o cinema), seja a partir da leitura dos livros de Nelson Werneck Sodré (MATTOS, 2015), autor considerado um dos grandes expoentes da presença do marxismo no âmbito da historiografia brasileira (DUCATTI, 2007). A perspectiva "de esquerda" presente em seus filmes, portanto, não é obra do acaso, mas está relacionada à sua própria formação enquanto cineasta.

No caso específico do filme Jango, o Dicionário de filmes brasileiros registrou que a produção do documentário foi financiada pela própria família de João Goulart, que tinha como

1 - A filmografia completa de Silvio Tendler é composta por vários outros filmes, além dos longas citados aqui, incluindo diversos curtas e médias-metragens, e pode ser consultada na internet pelo seguinte link: http://caliban.com.br/filmografia/. Acesso em: 27 abr. 2021. 
objetivo "restaurar a memória" e fazer "justiça" à figura do político que foi derrubado do cargo de presidente da República do Brasil pelo golpe de 1964 (SILVA NETO, 2002). Como consequência disso, uma das principais caracteristicas do documentário é uma postura muito favorável à figura de João Goulart, assumindo um tom de elogio em relação ao seu personagem principal.

0 fato de Jango mostrar João Goulart de maneira positiva não agradou ao governo da ditadura quando do lançamento da obra. Em matéria escrita por Susana Schild e publicada no Jornal do Brasil no dia 15 de fevereiro de 1984, está registrado que o filme de Tendler foi inicialmente barrado pela censura. Na mesma matéria, o próprio cineasta deu uma declaração reconhecendo que o seu documentário tinha um forte caráter político, assumindo uma postura crítica em relação ao golpe de 1964 e à ditadura que se instalou no País depois daquele evento. 0 documentário, portanto, objetivava tratar de alguns momentos recentes da história política do Brasil no sentido de fazer uma defesa do Estado democrático de direito em meio ao processo de abertura política que se vivia na época em que o filme foi lançado (meados dos anos 1980), mesmo sendo essa abertura cheia de contradições - afinal, o filme de Tendler foi inicialmente censurado. 0 tom "simpático" do documentário em relação a João Goulart, de acordo com Silvio Tendler, também se relacionava ao fato de que, segundo o cineasta, Goulart teria sido o único presidente a "mexer na estrutura social do país", desafiando certamente os interesses de determinados grupos políticos e econômicos (SCHILD, 1984, p. 1).

Na mesma edição do dia 15 de fevereiro de 1984 do Jornal do Brasil, Villas-Bôas Corrêa também publicou um pequeno texto sobre o filme de Silvio Tendler, no qual afirmou que o fato de o filme não ser imparcial/neutro não devia ser visto como "um defeito", mas sim como uma marca do documentário de Silvio Tendler. De acordo com Corrêa (1984, p. 1), a parcialidade da obra podia ser claramente vista na "má vontade com o outro lado", como, por exemplo, na "seleção de trechos caricaturais do depoimento desconchavado do General Andrada Muricy".

De acordo com os pesquisadores Jean-Claude Bernardet e Alcides Freire Ramos (2013), Jango é um filme que busca refletir não só sobre a trajetória de um político brasileiro, mas também sobre a conjuntura mais ampla da história recente do Brasil (décadas de 1950, 1960, 1970). Segundo a análise feita por Bernardet e Ramos (2013), o referido documentário de Silvio Tendler tem como uma de suas principais características o fato de elaborar uma imagem muito positiva do político brasileiro João Goulart, fazendo uso de todo um conjunto de estratégias narrativas para produzir no espectador a sensação de que aquilo que se vê na tela é a verdade dos fatos. A forma da montagem e a ordem em que são exibidas as entrevistas no filme são essenciais para que a versão da história mais favorável a Goulart seja tomada como a mais correta por parte daquele que eventualmente estiver assistindo ao documentário. Portanto, Jango não é uma obra neutra, pois "o mecanismo do filme é ideológico". Por 
mais que apresente imagens de arquivo e entrevistas daqueles que viveram os eventos ali narrados, Jango deve ser entendido como fruto de opções estéticas e políticas muito específicas, e não como uma obra que mostra uma pretensa "verdade única" acerca da História (BERNARDET; RAMOS, 2013).

É inegável o fato de Jango ser um filme muito eficiente na sua proposta de produzir determinados efeitos no espectador. Pensemos, por exemplo, na leitura da obra que foi feita pelo pesquisador Jorge Ferreira em um pequeno texto publicado em 2001, no qual a sua análise acerca do documentário foi na maior parte do tempo direcionada para os pontos de contato entre a interpretação dos fatos feita pelo filme de Silvio Tendler e as informações disponíveis na bibliografia especializada sobre o período histórico retratado no filme. De modo geral, Ferreira (2001) demonstrou concordar bastante com o conteúdo da narrativa do filme Jango, o que nos ajuda a pensar na eficácia do "efeito de verdade"2 dessa obra cinematográfica junto a uma parte do público espectador. Apenas em um momento específico - quando tratou do trecho do filme Jango que descreveu o golpe de 1964 como um acontecimento provocado quase apenas por uma grande conspiração - Jorge Ferreira (2001) afirmou que discordava da versão da história elaborada por Silvio Tendler.

Mas o que tornou possivel tal eficácia do filme Jango em apresentar uma narrativa com a qual um pesquisador como Jorge Ferreira fora levado a concordar quase que totalmente? Uma parte da resposta certamente está relacionada ao próprio contexto em que o documentário foi lançado. Segundo a pesquisadora Flávia Biroli (2006), em meados dos anos 1980, no bojo do processo de redemocratização do Brasil, tornou-se recorrente em parte da imprensa brasileira a vinculação de textos e reportagens que retratavam a figura de João Goulart de maneira positiva, em oposição ao golpe de 1964 e à ditadura, que eram retratados de maneira negativa. Segundo Biroli (2006), no ano de 1984 (mesmo ano de lançamento do filme Jango), 45,5\% dos textos jornalísticos analisados pela pesquisadora vincularam Goulart às reformas de base, enquanto 22,7\% dos textos o vincularam a um projeto democrático, e apenas 13,5\% o associaram a uma tentativa de se implantar uma ditadura de esquerda ("comunista") no Brasil. Em pleno contexto de abertura política, portanto, houve o predomínio de uma caracterização positiva de João Goulart na grande imprensa. A pesquisadora também observa que, paralelamente a isso, na imprensa da época houve o predomínio de uma caracterização negativa do golpe de 1964, de modo que, nas palavras da autora, aos poucos, João Goulart foi sendo "caracterizado como um 'outro' do golpe e da ditadura" (BIROLI, 2006, p. 14-15).

0 fato de tal tendência observada por Biroli (2006) ter começado a ser comum a partir dos anos 1980 é interessante porque coincide justamente com o período de produção e lançamen-

2 - Para uma reflexão mais aprofundada acerca da capacidade da imagem cinematográfica - particularmente no campo do cinema documentário - de produzir um "efeito de verdade" junto ao espectador, ver o trabalho de Bill Nichols (2009). 
to do filme Jango. Assim, tanto uma parte da imprensa da época quanto o documentário de Tendler interpretaram o recente processo histórico brasileiro retratando Goulart de uma maneira mais positiva em contraposição ao golpe de 1964 e à ditadura, que foram frequentemente retratados de maneira negativa no contexto da redemocratização do Pais. Nessa perspectiva, a avaliação do perfil de João Goulart passou a ser feita não apenas com base na figura do político em si, mas também levando em consideração tudo o que ocorreu no Brasil após a sua derrubada do poder. Desde então, Goulart não tem sido, portanto, pensado de maneira isolada em relação ao processo histórico, mas sim em relação ao golpe de 1964 e à ditadura.

Contudo, para entender como o filme Jango tornou-se tão eficaz no que diz respeito à veiculação de uma imagem positiva a respeito de João Goulart, faz-se necessária uma análise mais detalhada dos aspectos estéticos/formais da obra, sobretudo no que concerne à construção de João Goulart como um personagem histórico no filme. Esse será o objeto de nossas reflexões na próxima seção.

\section{A REPRESENTAÇÃO DE JOÃO GOULART COMO UM "HERÓI TRÁGICO" NO FILME JANGO}

No filme Jango, a trajetória política de João Goulart é abordada por meio de imagens de arquivo, de depoimentos e da narração em off, que, em conjunto, elaboram uma imagem bastante positiva do protagonista do filme. Pensemos, por exemplo, na sequência em que 0 documentário trata do contexto da renúncia do presidente Jânio Quadros, episódio ocorrido no final do mês de agosto de 1961. A reação de Goulart, então vice-presidente da República, a tal acontecimento é mostrada no filme de Silvio Tendler como um sinal de suas boas qualidades como líder político. No depoimento dado pelo jornalista Raul Ryff, é dito que Goulart estava em Cingapura quando recebeu a notícia da renúncia de Quadros. Segundo Ryff, Goulart até aceitou tomar um champanhe naquele momento, mas "não para comemorar a chegada à Presidência", mas sim "em homenagem ao imprevisivel"3. 0 próprio jornalista, que é filmado por uma câmera estática que focaliza o seu rosto, afirma que Goulart era um sujeito precavido e "pé no chão". Esse depoimento de Ryff é exibido antes mesmo de os créditos iniciais de Jango surgirem na tela, ou seja, é uma sequência inicial que serve para apresentar, logo no começo do filme, o personagem principal da obra.

Após a exibição dos créditos iniciais - acompanhados por fotografias que mostram Goulart em diferentes momentos de sua vida e por uma música interpretada por Milton Nascimento,

3 - Trecho transcrito diretamente do filme Jango (1984) [transcrição nossa, não publicado]. Todos os trechos citados são retirados do referido filme, salvo quando vier indicado por referência bibliográfica específica. 
música que assume um tom melancólico -, imagens mostram a cidade de São Borja, no Rio Grande do Sul, a qual é descrita pela narração como "berço e túmulo de dois presidentes": Getúlio Vargas e João Goulart. A narração feita pelo ator José Wilker, portanto, já estabelece desde o início uma ligação entre os dois políticos brasileiros. Ainda nessa sequência, temos imagens do quarto de Goulart, no qual há uma série de fotografias do político. A narração afirma que, da estreia de Goulart na vida pública, em 1947, até o golpe de 1964, houve um amadurecimento do sentimento nacionalista e o compromisso com a justiça social, que foram, ainda de acordo com a narração em off, as razões trágicas do destino comum de Vargas e Goulart.

Para além da ligação de João Goulart com a figura de Getúlio Vargas ${ }^{4}$ o documentário também elabora uma imagem positiva de Jango com base na análise de diversos detalhes a respeito da vida de seu protagonista. Em certo momento do filme, são exibidas fotografias em preto e branco que mostram Goulart durante a sua infância, na escola e junto da família. A narração em off informa o espectador de que João Goulart nasceu em $1^{\circ}$ de março de 1918, tendo sido o sétimo filho de um casal de "ricos proprietários de terras". Todavia, apesar de tal origem social, de acordo com a narração, Goulart teve uma convivência espontânea com os peões da fazenda. No que diz respeito ao seu tempo de juventude na cidade de Porto Alegre, a narração afirma que Goulart viveu entre a alegria da vida boêmia e os rigores da academia.

0 texto da narração também registra que Goulart formou-se em Direito e fez uma rápida escalada política ao ocupar os cargos de deputado estadual, deputado federal e secretário de Interior e Justiça antes de chegar ao Ministério do Trabalho, no ano de 1953. A respeito do periodo em que Goulart ocupou o cargo de ministro do Trabalho, a narração em off enfatiza o fato de ele ter concedido aos trabalhadores brasileiros um aumento de 100\% no salário mínimo. Trata-se de um trecho do filme Jango em que se elabora uma imagem positiva do político, pois Goulart é descrito como alguém que buscou ficar do lado dos trabalhadores. De acordo com a perspectiva adotada pelo filme, portanto, o homem adulto confirmava o jovem que tinha boa convivência com os peões da fazenda de seus pais.

Em outro momento do filme, a narração em off afirma que João Goulart "pretendia reformar a face do capitalismo brasileiro diminuindo as desigualdades sociais, dando-Ihe um aspecto mais humano, menos selvagem". Tal postura de Goulart gerava as mais variadas reações entre seus aliados porque, ainda de acordo com a narração, as pessoas não sabiam ao certo se Goulart queria ou não "acabar com o capitalismo". Diante disso, o texto da narra-

\footnotetext{
4 - Vale lembrar aqui o fato de que, como bem demonstrou Angela de Castro Gomes (2005), apesar de Getúlio Vargas ter assumido uma postura autoritária durante o periodo em que governou o Brasil, ao longo do tempo construiu-se e consolidou-se um verdadeiro mito em torno de sua figura. 0 resultado disso foi que Vargas tornou-se um personagem histórico lembrado de maneira bastante positiva em diversos segmentos da sociedade brasileira.
} 
ção complementa: "[Goulart] Tinha que compor sua estratégia de ação lutando ainda contra o desconforto pessoal de ser um presidente rico num pais pobre".

É curioso que, embora seja dito que Goulart pretendia dar uma face "menos selvagem" ao capitalismo brasileiro, as imagens que acompanham esse trecho da narração do filme sejam compostas por fotografias em preto e branco que mostram Goulart caçando em uma área rural, com uma arma nas mãos. 0 aparente desencontro entre imagem e texto pode confundir o espectador menos atento. Contudo, em nossa avaliação, as imagens de Goulart praticando a caça servem para ressaltar que ele fazia parte das camadas mais abastadas da sociedade, já que o próprio texto lido pela voz de José Wilker lembra que Jango era um "presidente rico". Aqui, Goulart aparece de maneira elegante, com a camisa por dentro da calça, os cabelos penteados, a postura ereta e sendo fotografado enquanto caça - ou faz pose de que está caçando. A caça aqui não é uma prática voltada para a obtenção de algum alimento extremamente necessário para a sobrevivência, mas sim um exercício de lazer, o que reforça a condição social elevada de Goulart. Não se trata de mero detalhe. Muito pelo contrário, essa sequência do documentário é essencial para a construção de João Goulart como um "herói trágico" na narrativa do filme, afinal, como bem apontou Flávio René Kothe (1985) , o clássico "herói trágico" é, quase sempre, justamente alguém que ocupa uma posição social superior.

Quanto à afirmação de que Goulart tinha um "desconforto pessoal de ser um presidente rico num país pobre", ela tem a finalidade de elaborar uma imagem de Jango segundo a qual ele era um presidente efetivamente preocupado com a questão social. E é por isso que o documentário de Silvio Tendler procura enfatizar o comprometimento de Goulart com a realização das reformas de base. Quando o filme aborda o comício da Central do Brasil, realizado em março de 1964, por exemplo, há um breve depoimento do jornalista Raul Ryff segundo o qual, embora muitas das reformas de base "talvez não fossem possíveis de realizar", João Goulart teria declarado que, diante do desconforto de muitos atores sociais em relação à realização do comício da Central do Brasil, ele preferia defender as reformas de base e, se fosse o caso, "cair de pé" por causa disso.

A fala do jornalista, portanto, descreve Goulart como um homem mais preocupado com a questão social do que com a própria manutenção de sua posição individual no poder. Jango é retratado no filme como uma espécie de herói disposto a se sacrificar em prol de toda a coletividade, bem aos moldes do que foi dito pelo filósofo Georg Wilhelm Friedrich Hegel (1995), segundo o qual as ações dos grandes homens extrapolam os limites impostos pelos interesses individuais, alcançando a esfera pública. Na perspectiva do filósofo, o herói não necessariamente alcança a felicidade no plano individual. 0 herói pode cair ou mesmo ser derrubado por outros homens justamente porque coloca a realização do espírito universal na história acima dos interesses individuais, o que certamente desagrada aos homens que não são tão "nobres" quanto ele (HEGEL, 1995). É nesse sentido que, em nossa avaliação, a fala 
do jornalista Raul Ryff, segundo a qual Goulart preferia "cair de pé" reforça a imagem "heroica" de João Goulart que é construida no filme de Silvio Tendler.

Todavia, há outro elemento importante no depoimento de Raul Ryff. Merece atenção o fato de que, segundo Ryff, talvez Goulart tenha sido um pouco ingênuo ao acreditar que as reformas de base pudessem ser efetivamente colocadas em prática no Brasil naquela época (meados dos anos 1960). Tal "ingenuidade" pode ser pensada como um "erro" cometido pelo "herói" João Goulart, de acordo com a narrativa fílmica. Porém, é preciso esclarecer: tal ingenuidade aqui não é simplesmente uma característica negativa do político, pois ela também implica que Goulart era alguém "puro de coração", em especial se fosse comparado a outros personagens da política nacional da época. A caracterização de Jango no documentário é, mais uma vez, bastante positiva. Retomando as considerações de Roberto Machado (2006) a respeito da forma da narrativa trágica, nota-se que, no âmbito de uma tragédia, um elemento importantíssimo é justamente a questão em torno do "erro" cometido pelo herói trágico, pois o erro contribui para que o espectador/leitor da tragédia sinta compaixão em relação ao protagonista da tragédia. Assim, embora a narrativa trágica mostre o herói como alguém que cometeu um erro, ela ainda o caracteriza de maneira positiva (MACHADO, 2006).

Essa caracterização positiva de Jango permite que o espectador do filme de Silvio Tendler se identifique com o personagem. E tal identificação não se dá apenas pelas ações de Goulart na vida pública, mas também pelas imagens da vida pessoal e familiar do político que são apresentadas no documentário, que o mostram como um homem de hábitos simples e que apreciava o convívio com a família. 0 documentário, portanto, humaniza a figura do "herói" João Goulart, aproximando-a do público espectador. Tal "humanização do herói" também é visível na sequência que aborda a vida de João Goulart no exílio, após o golpe de 1964. A tela exibe imagens de um Jango envelhecido e fragilizado. A narração em off complementa o que se vê na tela, por meio das seguintes palavras: "O fazendeiro Jango, exilado no Uruguai, vivia a angústia e as incertezas da espera. A volta tão desejada não tinha data marcada. A amargura daqueles dias tirava até mesmo dos aniversários dos filhos o sabor da festa". Aqui, a câmera faz um movimento de travelling, passando de baixo para cima por uma fotografia em preto e branco que mostra Jango cortando um bolo de aniversário. Primeiro, a câmera foca a mão de Goulart para, em seguida, focar seu rosto. Jango aparece triste, emocionalmente distante de qualquer clima festivo. A imagem procura confirmar, portanto, o texto lido pela voz over que faz a narração do filme.

Todavia, mesmo nesse momento de fragilidade, Goulart é mostrado como o herói do filme porque, apesar das dificuldades, ele ainda era capaz de lutar em defesa da democracia. A narração em off diz: "O desejo de ver o Brasil redemocratizado fez Jango, no exílio, aliar-se a Carlos Lacerda e a JK [Juscelino Kubitschek] para formar a Frente Ampla que logo foi proibida". A narrativa fílmica reforça assim a imagem positiva do herói: mesmo por baixo, em um 
momento difícil, Jango continuava se esforçando para fazer algo em prol de seu país. 0 fato de ele ter se aliado a Carlos Lacerda, personagem que havia sido um dos seus opositores mais fortes quando Goulart ocupava a Presidência da República, reforça a ideia de que, como um verdadeiro herói, Goulart estava disposto a fazer o que tinha que ser feito.

No filme, Jango é um herói trágico que em boa parte do documentário é mostrado de maneira bastante positiva, e que no final da narrativa aparece fragilizado e isolado. Segundo o documentário, após ser tirado do poder pelo golpe de 1964 e exilado no exterior, Goulart teve que viver sob um clima de tensão - especialmente por causa da repressão violenta imposta não só pela ditadura brasileira, mas presente em diversos pontos da América Latina, com a chamada Operação Condor, segundo nos informa a narração em off do filme. Perto de seus minutos finais, o documentário Jango desenvolve a ideia de que, instalados os governos ditatoriais no Brasil e em outros países da América Latina nas décadas de 1960 e 1970, não houve outra escapatória para João Goulart que não fosse a morte. A própria situação de "sem saída" na qual Goulart se viu preso nos últimos anos de sua vida, diga-se de passagem, reforça a condição trágica do personagem na narrativa do filme ${ }^{5}$. Na sequência final do documentário, diversas imagens de arquivo mostram um João Goulart velho e frágil, no exilio. Outras imagens fazem um breve flashback de sua trajetória de vida, resgatando cenas de um Goulart mais jovem e ativo na política. Outras imagens, enfim, mostram-no morto, dentro de um caixão, e a reação das pessoas à sua morte, quando uma multidão compareceu ao seu velório e ao seu enterro. Boa parte dessa sequência tem como trilha sonora a música Coração de estudante, de Milton Nascimento, canção que auxilia as imagens a criar uma emoção muito grande ao final do filme.

Do ponto de vista assumido pelo filme de Silvio Tendler, Goulart foi o personagem que defendeu a justiça social, desafiando forças que se revelaram muito maiores que ele, e acabou sendo derrubado por isso. Porém, a avaliação feita pelo documentário é de que, embora possa ter falhado ao não evitar o golpe de 1964, João Goulart estava do lado certo da História, ao levantar a bandeira das reformas de base e da justiça social. 0 filme, portanto, julga positivamente as ações de Goulart do ponto de vista moral ao construir a sua narrativa. A obra de Silvio Tendler posiciona-se claramente contra a violência e o arbítrio praticados pela ditadura, dai o fato de o documentário ser mais favorável à figura do personagem que foi derrubado do poder por essa mesma ditadura, instalada no País em 1964. Não por acaso, o filme termina com a imagem do jazigo em que Goulart foi sepultado, com a câmera focando

5 - Ao refletir sobre os aspectos das narrativas que adotam a forma da tragédia, Hayden White (2008) observou que a tragédia geralmente termina de maneira sombria, sobretudo se comparada à comédia. Na tragédia, segundo White, há uma constatação de que, tendo em vista as condições históricas que escapam ao controle dos homens, o poder da ação humana individual é muito limitado, não havendo o que se fazer diante de certas situações. Ou seja, as narrativas trágicas normalmente apontam para o fato de que não há saídas seguras para o homem diante da dura realidade do mundo. 
a fotografia de Goulart, uma melancólica música de fundo na trilha sonora e um poema de Fernando Brant sendo exibido na tela, que diz:

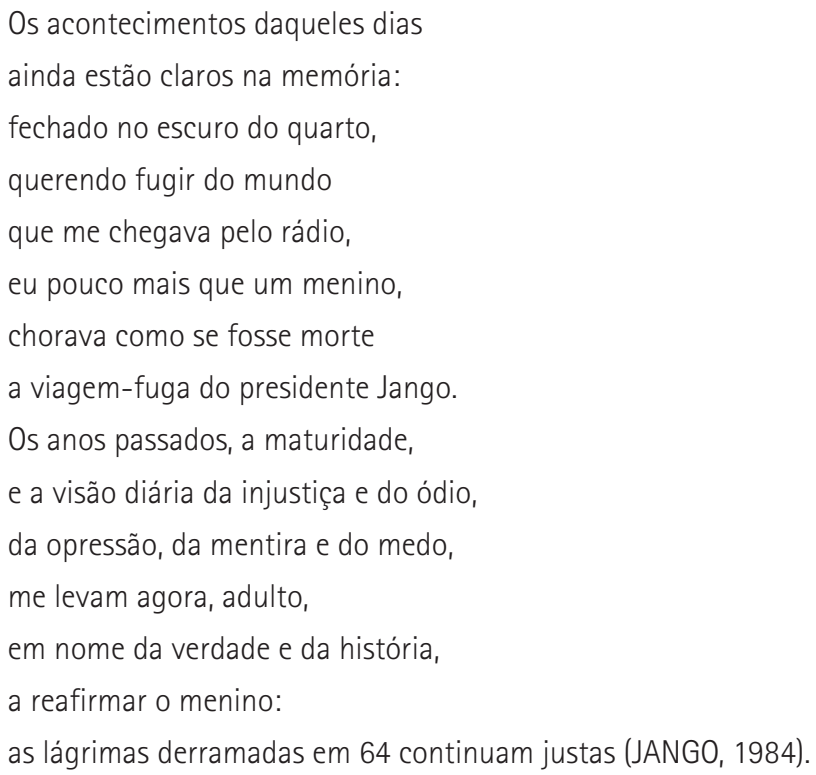

Como se vê, é por meio da comparação entre o projeto de país defendido por João Goulart e o projeto de país que foi colocado em prática pela ditadura que o protagonista do documentário é mostrado de maneira positiva. Foi para reforçar a sua oposição à violência do regime ditatorial que o cineasta Silvio Tendler se mostrou favorável à figura de Jango. João Goulart serviu, assim, de símbolo da democracia e da justiça social na narrativa do documentário. No contexto do lançamento do documentário, em meio ao processo de redemocratização do Brasil, ao citar o poema de Brant para dizer que "as lágrimas derramadas em 64 continuavam justas", o filme Jango operou no mesmo sentido indicado por Flávio Kothe (1985, p. 26) acerca do herói trágico:
Ele [o herói trágico] como que perde o poder terreno para conquistar um poder espiritual; ele como que se despe do agora, para, lá debaixo, resplandecer elevada sabedoria, transcen- dendo todos os seus juizes e algozes. À custa do próprio sangue, torna-se mensageiro do passado para o futuro, como as almas dos mortos eram evocadas, convocadas a compare- cerem ao presente. 0 sangue trágico do presente conclama o passado para superar pela sabedoria a tragédia.

Em Jango, a questão não é a de simplesmente se construir uma imagem positiva de João Goulart enquanto personagem histórico, pois tal exercício foi feito no filme tendo em vista 
o momento político vivido pelo Brasil quando da produção e do lançamento do documentário. 0 cineasta Silvio Tendler trouxe à tona os acontecimentos de um passado recente do país para mandar uma mensagem para o seu tempo presente e para o futuro. Por meio do protagonista do filme, Tendler marcou a sua posição contra a ditadura ao apresentar em seu documentário um exemplo do que seria um "bom governante". 0 elogio a Goulart significou também a crítica ao tipo de governo montado pela ditadura militar no Brasil. Tendler mostrou Goulart como um líder político fiel à democracia e à justiça social, em oposição ao autoritarismo e aos problemas sociais existentes na ditadura. João Goulart pôde ser, assim, o herói trágico do filme Jango justamente porque a ditadura era a vilã a ser combatida quando o documentário foi lançado.

\section{CONSIDERAÇÕES FINAIS}

Quais reflexões podemos fazer a respeito da escrita da História a partir da análise do documentário Jango? Uma primeira observação a ser feita é que a elaboração de uma narrativa histórica envolve um conjunto de opções estéticas que, para além da produção de conhecimento e da veiculação de certas informações, também tem o potencial de inserir uma forte carga de emoção nos episódios narrados. 0 filme Jango faz isso muito bem, pois não só apresenta diversos detalhes a respeito da trajetória de João Goulart e da recente história política do Brasil, mas também emociona o espectador. Diante do documentário, os historiadores são levados a refletir sobre os elementos formais de seus próprios textos. 0 filme Jango nos instiga a pensar na seguinte questão: as narrativas escritas pelos historiadores têm sido capazes não só de informar, mas também de emocionar os seus leitores?

Não ignoramos aqui as inúmeras diferenças entre uma narrativa fílmica e uma narrativa escrita, afinal, um texto não pode fazer tudo que um filme faz, e vice-versa, mas a análise do filme Jango nos estimula a pensar no quanto pode ser produtivo para o historiador preocupar-se mais com os elementos estéticos e formais de seus textos, já que eles serão lidos por outras pessoas. Não se trata de meramente "enfeitar" os textos com "ornamentos estéticos", mas sim de não perder de vista a não separação entre razão e emoção. Um texto escrito por um historiador pode ao mesmo tempo fazer jus aos aspectos metodológicos e racionais da pesquisa histórica e proporcionar uma experiência estética ao leitor, tornando o conteúdo do texto mais significativo.

A análise do modo como o documentário Jango construiu uma imagem bastante específica do seu personagem principal também é útil para a reflexão acerca da escrita da história na medida em que o historiador, seja quando escreve um texto, seja quando ministra uma aula ou uma palestra, também se vê diante do desafio de descrever vários personagens his- 
tóricos e suas ações. Se a escrita da história nunca se dá a partir de uma posição neutra/ imparcial, cabe ao historiador estar bastante atento ao modo como descreve os personagens históricos, pois a maneira como uma descrição é feita sempre está articulada a um determinado posicionamento político e ideológico e pode gerar os mais diversos efeitos no público leitor/espectador.

0 filme Jango nos instiga a pensar, enfim, no papel do indivíduo na história. Uma questão com a qual o historiador deve lidar ao escrever diz respeito às relações entre as ações individuais e os seus efeitos nos processos históricos mais amplos. Para ficarmos no conteúdo do documentário de Silvio Tendler, pensemos na seguinte pergunta: em que medida João Goulart, por meio de suas ações e decisões, teve responsabilidade nos (des)caminhos trilhados pela sociedade brasileira como um todo após o golpe de 1964? A resposta dada pela narrativa do filme Jango é muito clara: é preciso levar em conta não apenas as ações de João Goulart, mas também o contexto histórico mais amplo da época e as ações empreendidas por outros personagens que viveram naquele mesmo período e se envolveram nos conflitos político-ideológicos existentes no Brasil naquele contexto. Como bem disseram Jorge Ferreira e Angela de Castro Gomes no livro intitulado 1964: "os processos históricos não são tão simples e não devem ser tão personalizados. Os indivíduos, com suas escolhas, são decisivos. Mas há sempre vários indivíduos e várias escolhas. E também há o contexto político de uma época" (FERREIRA; GOMES, 2014, p. 137).

Lançado há mais de três décadas, o documentário Jango ainda merece ser visto com atenção pelos historiadores não apenas por apresentar diversas informações sobre alguns dramáticos episódios da recente história política brasileira, mas também por nos fazer pensar em como essa história pode ser escrita.

\title{
The construction of João Goulart as a historical character in the film Jango (1984), directed by Silvio Tendler: brief reflections on writing history from the documentary cinema
}

\begin{abstract}
This article addresses the relationship between Documentary Cinema and History of Brazil from the film Jango (1984), directed by Silvio Tendler. Through the analysis of the formal/aesthetic aspects of the documentary, especially with regard to the construction of the historical character João Goulart within the film narrative, we seek to demonstrate how the political-ideological positioning of the filmmaker Silvio Tendler took place in the context of production and release of the movie. The analysis of the documentary shows that the film narrative built by him has as one of its main characteristics a series of narrative strategies (testimonies, editing, soundtrack, image selection, voice over narration) that contribute to the politician João Goulart being described in the film in a very positive way. We argue that, in the documentary, João Goulart plays the role of a "tragic hero" within the scope of recent Brazilian political history. In this sense, we draw
\end{abstract}


attention to the fact that the aesthetic/formal elements of the documentary were not defined at random, but rather based on the political-ideological positioning assumed by the filmmaker when the film was produced and released, a time when Brazil was in the process of transition from the dictatorship to redemocratization. In addition to establishing a dialogue between the documentary and the historical context in which it was produced and released, we intend to demonstrate how the film raises very pertinent questions about the writing of History.

Keywords: Documentary cinema. Silvio Tendler. History of Brazil. João Goulart. Tragic hero.

\section{REFERÊNCIAS}

BERNARDET, J.-C.; RAMOS, A. F. Cinema e história do Brasil. 4. ed. rev. São Paulo: Ediç̧ões Verona, 2013.

BIROLI, F. João Goulart e o golpe de 1964 na imprensa, da transição aos dias atuais: uma análise das relações entre mídia, política e memória. In: CONGRESSO ANUAL DA ASSOCIAÇÃO BRASILEIRA DE PESOUISADORES DE COMUNICAÇÃO E POLÍTICA, 1., 2006, Salvador. Anais [...]. Salvador: Compolítica, 2006. p. 1-25. Disponivel em: http://www.compolitica.org/ home/wp-content/uploads/2010/11/Biroli_2006.pdf. Acesso em: 17 abr. 2021.

CORRÊA, V.-B. Como morreu a democracia. Jornal do Brasil, Rio de Janeiro, 15 fev. 1984. Caderno B, p. 1.

DUCATTI, I. Nelson Werneck Sodré, historiador. Fênix: Revista de História e Estudos Culturais, ano 4, v. 4, n. 1, p. 1-17, jan./fev./mar. 2007. Disponivel em: https://www.revistafenix.pro.br/ revistafenix/article/view/769/732. Acesso em: 27 abr. 2021.

FERREIRA, J. Como as sociedades esquecem: Jango. In: SOARES, M. de C.; FERREIRA, J. (org.). A história vai ao cinema: vinte filmes brasileiros comentados por historiadores. Rio de Janeiro: Record, 2001. p. 161-178.

FERREIRA, J.; GOMES, A. de C. 1964: o golpe que derrubou um presidente, pôs fim ao regime democrático e instituiu a ditadura no Brasil. Rio de Janeiro: Civilização Brasileira, 2014.

FILMOGRAFIA. Caliban Produções Cinematográficas, Rio de Janeiro. Disponível em: http:// caliban.com.br/filmografial. Acesso em: 27 abr. 2021.

GAY, P. O estilo na história: Gibbon, Ranke, Macaulay, Burckhardt. Tradução Denise Bottmann. São Paulo: Companhia das Letras, 1990.

GOMES, A. de C. A invenção do trabalhismo. 3. ed. Rio de Janeiro: Editora FGV, 2005. 
HEGEL, G. W. F. A razão na história: introdução à filosofia da história universal. Tradução Artur Morão. Lisboa: Edições 70, 1995.

JANGO. Direção: Silvio Tendler. Roteiro: Silvio Tendler e Mauricio Dias. Produção: Hélio Paulo Ferraz. Produtores Associados: Denize Goulart, Antônio José da Matta, Francisco Sérgio Moreira, Geraldo Ribeiro, José Wilker, Lúcio Kodato, Maurício Dias, Milton Nascimento, Sílvio Tendler e Wagner Tiso. Fotografia: Lúcio Kodato. Sonografia: Geraldo Ribeiro. Texto: Maurício Dias. Narração: José Wilker. Montagem: Francisco Sérgio Moreira. Trilha Sonora e Música Original: Wagner Tiso e Milton Nascimento. Canção: Enquanto seu lobo não vem: Caetano Veloso. Companhia Produtora: Caliban Produções Cinematográficas e Rob Filmes. Distribuição: Caliban Produções Cinematográficas. Rio de Janeiro: Caliban Produções Cinematográficas, 1984. DVD (117 min), son., color./p\&tb, 35mm.

KOTHE, F. R. O herói. São Paulo: Ática, 1985.

LABAKI, A. Sílvio Tendler ampliou discurso histórico do cinema brasileiro. Folha de S.Paulo, São Paulo, 21 jun. 2018. Disponivel em: https://www1.folha.uol.com.br/amp/ilustrada/2018/06/silvio-tendler-ampliou-discurso-historico-do-cinema-brasileiro.shtml. Acesso em: 27 abr. 2021.

MACHADO, R. O nascimento do trágico: de Schiller a Nietzsche. Rio de Janeiro: Jorge Zahar, 2006.

MALERBA, J. Os historiadores e seus públicos: desafios ao conhecimento histórico na era digital. Revista Brasileira de História, São Paulo, v. 37, n. 74, p. 135-154, jan./abr. 2017. Disponivel em: http://www.scielo.br/pdf/rbh/v37n74/1806-9347-rbh-2017v37n74-06.pdf. Acesso em: 27 abr. 2021.

MATTOS, R. Entrevista com Silvio Tendler: política e cultura de esquerda na obra de um cineasta engajado. Blog Junho, 6 jul. 2015. Disponivel em: http://blogjunho.com.br/entrevista-com-silvio-tendler-politica-e-cultura-de-esquerda-na-obra-de-um-cineasta-engajado/. Acesso em: 27 abr. 2021.

MIRANDA, L. F. Dicionário de cineastas brasileiros. São Paulo: Secretaria de Estado de Cultura: Art Editora, 1990.

NICHOLS, B. Introdução ao documentário. Tradução Mônica Saddy Martins. 4. ed. Campinas: Papirus, 2009.

RICOEUR, P. Tempo e narrativa: a intriga e a narrativa histórica. Tradução Claudia Berliner. São Paulo: Martins Fontes, 2010a. v. 1.

RICOEUR, P. Tempo e narrativa: o tempo narrado. Tradução Claudia Berliner. São Paulo: Martins Fontes, 2010b. v. 3. 
SCHILD, S. "Jango": a história que começa a ser contada. Jornal do Brasil, Rio de Janeiro, 15 fev. 1984. Caderno B, p. 1.

SILVA NETO, A. L. da. Dicionário de filmes brasileiros. São Paulo: Futuro Mundo Gráfica \&t Editora, 2002.

WHITE, H. Meta-história: a imaginação histórica do século XIX. Tradução José Laurênio de Melo. 2. ed. São Paulo: Edusp, 2008. 